\title{
Pendidikan Karakter di Sekolah Menengah Kejuruan (Studi Kasus Pembelajaran IPS di SMK se-Kecamatan Margoyoso Pati)
}

\author{
Abdul Karim \\ IAIN Kudus, Indonesia \\ abdulkarim@iainkudus.ac.id \\ Retno Susilowati \\ IAIN Kudus, Indonesia \\ retnosusilowati@iainkudus.ac.id \\ Muslim \\ IAIN Kudus, Indonesia \\ muslimabdurrasyid2@gmail.com
}

\begin{abstract}
This study aims to describe the character education in SMK in Margoypso District. The type of research is descriptive qualitative research. Collecting data by using interviews, observation and documentation. The data analysis uses data collection steps, data reduction, data presentation and drawing conclusions. The results of the study show that: The media used in character education for students in Vocational High Schools in Margoyoso District are: 1) Exemplary Media; 2) Habituation Media; 3) Meditation/dhikr; 4) Indoctrination; 5) Behavior / Personality. The study found that all teachers had (1) a steady personality, (2) a stable personality, (3) mature, and (4) wise because the learning time in the class of students could be conditioned. It's just that there are still some students who seem anxious or not focused in the learning process in class.
\end{abstract}

Keywords: Social Studies Learning; Character Education; Vocational High School 


\begin{abstract}
Abstrak
Penelitian ini bertujuan untuk mendiskripsikan Pendidikan karakter yang ada di SMK se Kecamatan Margoypso. Jenis peneltian adalah penelitian deskriptif kualitatif. Pengumpulan datanya dengan menggunakan wawancara, observasi dan dokumentasi. Analisis datanya menggunakan langkah pengumpulan data, reduksi data, penyajian data dan penarikan kesimpulan. Hasil peneltian menunjukkan bahwa: Media yang digunakan dalam pendidikan karakter kepada peserta didik di SMK se-Kecamatan Margoyoso adalah: 1) Media Keteladanan; 2) Media Pembiasaan; 3) Meditasi/dzikir; 4) Indoktrinasi; 5) Behivior/Kepribadian. Penelitian menemukan bahwa semua guru mempunyai (1) kepribadian mantap, (2) kepribadian stabil, (3) dewasa, dan (4) arif karena waktu pembelajaran di dalam kelas peserta didik dapat terkondisikan. Hanya saja masih ada beberapa peserta didik yang kelihatan kegelisahan atau tidak fokus dalam proses pembelajaran di kelas.
\end{abstract}

Kata kunci: Pembelajaran IPS; Pendidikan Karakter; Sekolah Menengah Kejuruan

\title{
A. Pendahuluan
}

Peran guru dalam proses pembelajaran sangat besar pengaruhnya terhadap tingkah laku anak didik. Untuk dapat mengubah tingkah laku anak didik sesuai dengan yang diharapkan, guru dapat menggunakan seluruh komponen pendidikan sehingga proses belajar mengajar tersebut berjalan dengan baik. Dalam kegiatan pembelajaran guru akan selalu diamati, diperhatikan, didengar, dan ditiru bahkan dinilai siswanya. Bagaimana penampilan guru di kelas, kepribadiannya, kemampuannya menguasai materi pelajaran, kemampuan mengajar, perhatian terhadap siswa, hubungan antara siswa dengan guru, sikap dan tingkah lakunya selama kegiatan pembelajaran berlangsung. Dengan demikian guru itu bisa menjadi suri tauladan bagi peserta didiknya.

Guru sebagai suri tauladan akan menjadikan karakter peserta didik yang tangguh. Penerapan pendidikan karakter diperlukan dalam meningkatkan kualitas pendidikan. Pendidikan karakter dapat diterapkan dalam proses pembelajaran. Pendidikan karakter memiliki tujuan untuk mengoptimalisasikan segala potensi luhur yang ada pada diri manusia. Manusia dijadikan oleh Allah dalam sebaik-baik bentuk atau kejadian, baik fisik maupun psikisnya, serta dilengkapi dengan berbagai alat potensial dan potensi-potensi dasar (fitrah) yang dapat dikembangkan dan diaktualisasikan secara maksimal melalui proses pendidikan (Muhaimin:2008)

Kemampuan pendidik mengelola pembelajaran akan mempengaruhi efektivitas pembelajaran dan tingkat keberhasilannya. Demikian juga kemampuan pendidik dalam 
membimbing belajar, bagaimana cara internalisasi pendidikan karakter, pengambilan keputusan dengan tepat, dan memecahkan masalah diri/peserta didiknya, juga akan mendukung keberhasilan diri, peserta didik, dan sekolahnya. Oleh karena itu, proses pembelajaran di kelas harus benar-benar dirancang sebaik mungkin oleh pendidik untuk mengembangkan potensi peserta didik secara optimal.

Peserta didik setingkat Sekolah Menengah Atas/Kejuruan pada umumnya mereka masih labil. Salah satu unsur penting dari proses kependidikan adalah guru. Guru mempunyai tanggung jawab mengantarkan peserta didik untuk mencapai tujuan pendidikan yang dicita-citakan. Untuk mencapai tujuan yang dicita-citakan tersebut, guru harus memenuhi kebutuhan peserta didik, baik spiritual, intelektual, moral maupun kebutuhan fisik peserta didik (Al-Rasyidin dan Syamsul Nizar:2005). Dengan demikian, perlu adanya sebuah konsep dalam internalisasi pribadi bagi seorang guru Pendidikan Agama Islam dalam penguatan pendidikan karakter peserta didik. Internalisasi sendiri bisa diartikan sebagai penggabungan atau penyatuan sikap, standar tingkah laku, pendapat, dan seterusnya di dalam kepribadian (J.P. Chaplin:2005).Internalisasi pribadi guru bisa melalui berbagai media, di antaranya: keteladanan, meditasi, indoktrinasi, perilaku, melalui model pembelajaran yang diberlakuakan, seperti full day school (FDS).

Latar belakang keluarga yang beragam, seperti tingkat ekonomi, pendidikan, dan status sosial menjadikan pembinaan sikap dan karakter siswa SMK di Margoyoso membutuhkan strategi tersendiri yang dapat memberikan pemahaman dan kesadaran agar pembinaan karakter memperoleh hasil yang baik. Faktor lain yang dapat mempengaruhi adalah kecenderungan masyarakat lingkungan lembaga pendidikan yang relatif padat penduduk dan ramainya kegiatan perekonomian, menjadikan kegiatan pengawasan dalam pembinaan karakter membutuhkan langkah yang serius, termasuk menumbuhkan sikap ket UU Nomor 20 Tahun 2003, Pasal 1). Dalam konteks mewujudkan tujuan pendidikan, khususnya keperibadian dan akhlak mulia, pemerintah telah menetapkan program pendidikan karakter.

Karakter adalah watak, tabiat, akhlak, atau kepribadian seseorang yang terbentuk dari hasil internalisasi berbagai kebajikan (virtues) yang diyakini dan digunakan sebagai landasan untuk cara pandang, berpikir, bersikap, dan bertindak. Hal ini mengandung pengertian bahwa karakter merupakan kebajikan yang ditanamkan pendidik melalui internalisasi atau memasukkan materi dan nilai yang mempunyai relevansi dalam membangun sistem berpikir dan berperilaku siswa. Karakter diajarkan dengan mengenalkan, memahamkan hingga mengajak siswa sehingga pada akhirnya mereka mampu mempraktekkan dan memaknainya sebagai sesuatu yang melekat dan menjadi tindakan perenungan (reflective action) serta mengembangkannya menjadi 
pusat keunggulan insani (center of human exellence). Jadi, pendidikan karakter dapat dimaknai sebagai pendidikan yang menekankan pada pembentukan (internalisasi) nilainilai positif (akhlak karimah) pada setiap anak. Dengan Latar belakang diatas, maka pada artikel ini akan meneliti tentang pendidikan karakter di SMK se-Kecamatan Margoyoso.

Penelitian ini menggunakan pendekatan kualitatif. Peneliti mengambil lokasi penelitian di lima SMK se-Kecamatan Margoyoso Pati, yaitu: SMK Cordova Margoyoso, SMK Salafiyah, SMK Gajah Mada 01 Margoyoso, SMK Kesuma Margoyoso, dan SMK Terpadu Nusantara. Peneliti mengambil lokasi tersebut, karena pemilihan dan penentuan lokasi tersebut dilatarbelakangi oleh beberapa pertimbangan atas dasar kekhasan, kemenarikan, keunikan dan sesuai dengan topik dalam penelitian ini. Adapun beberapa alasan yang cukup signifikan mengapa penelitian ini dilaksanakan pada kedua lembaga tersebut tersebut adalah alasan yang berkenaan dengan lokasi penelitian dan alasan yang bersifat substantif penelitian. Sumber data dalam penelitian ini bersumber dari manusia dan non manusia. Unsur manusia adalah seluruh guru IPS SMK se-Kecamatan Margoyoso Pati. Setelah mendapatkan data selanjutnya konfirmasi atas informan diperlukan. Sedangkan data non manusia meliputi dokumentasi dari masing-masing lokasi penelitian, aktivitas dan perilaku-perilaku yang dapat diamati.

Teknik yang digunakan peneliti dalam mengumpulkan data adalah observasi partisipan, wawancara mendalam, dokumentasi. Untuk memperoleh informasi yang dijadikan data utama dari lapangan penelitian, peneliti melakukan teknik wawancara dengan informan serta pihak lain yang terkait dengan data yang dibutuhkan. Wawancara dengan informan dilaksanakan di lokasi SMK se-Kecamatan Margoyoso Pati atau sesuai dengan permintaan responden. Adapun pihak yang akan diwawancarai adalah semua guru IPS terkait dengan obyek penelitian yakni internalisasi yang berada di SMK se-Kecamatan Margoyoso Pati. Studi dokumentasi dilakukan untuk memperoleh data sekunder yang bersifat administratif dan data kegiatan-kegiatan yang terdokumentasi baik di tingkat kelompok maupun di tingkat penyelenggara. Dalam penelitian ini dipergunakan data: keadaan jumlah guru, jumlah peserta didik, sejarah pendirian di SMK se-Kecamatan Margoyoso Pati, dan data lain yang relevan dan memperkaya informasi dalam penelitian ini. Untuk mengecek atau memeriksa keabsahan data mengenai penguatan pendidikan karakter di SMK se Kecamatan Margoyoso Pati tersebut berdasarkan data yang terkumpul, selanjutnya ditempuh beberapa teknik keabsahan data, meliputi: kredibilitas, transferabilitas, dependabilitas dan konfirmabilitas.

Analisis Data menggunakan Model Interaktif, yang mengasumsikan bahwa penelitian kualitatif merupakan upaya yang berlanjut, berulang, terus-menerus. 
Langkah-langkahnya adalah pengumpulan data, reduksi data. Secara metodis, pengguna metode fenomenologi melakukan langkah-langkah reduksi dalam tiga tahap berupa: (i) reduksi fenomenologis, (ii) reduksi eidetis, dan (iii) reduksi transendental. Peneliti melakukan teknik tabulasi data untuk mengklasifikasikan data sesuai kategori yang telah ditentukan. Teknik ini akan menunjukkan pola keterulangan data yang membantu peneliti mensintesiskan data. Penyajian data yang tertata dan sistematis juga memudahkan peneliti untuk mencermati kembali data yang terkumpul, lalu memutuskan tindakan reduksi data ataupun penggalian data yang lebih lengkap. Kesimpulan dalam penelitian kualitatif ialah temuan-temuan penelitian yang diperoleh dari mensintesiskan hubungan antara kategori data. Kesimpulan sementara biasanya sudah bisa ditangkap peneliti pada saat kegiatan di lapangan masih berlangsung. Karena itu, proses verifikasi pun dapat dilakukan selama penelitian masih berlangsung. Dengan demikian, peneliti dapat melakukan kegiatan pengumpulan data lagi jika proses verifikasi ternyata tidak tepat atau tidak dapat menjawab permasalahan penelitian.

Proses verifikasi dalam penelitian ini dilakukan dengan dua cara yaitu wawancara tidak terstruktur dengan pihak SMK se Kecamatan Margoyoso Pati yaitu guru untuk memverifikasi kesimpulan sementara peneliti terhadap data lapangan selama penelitian masih berlangsung, dan hasil kategorisasi dan sintesis data (ketika penelitian telah selesai) diverifikasi oleh salah seorang staf sekolah. Metode ini merupakan tahap reduksi transendental.

\section{B. Pembahasan}

\section{Partisipasi Pendidikan Karakter}

Secara etimologis, kata karakter (Inggris: character) berasal dari bahasa Yunani (Greek), yaitu charassein yang berarti "to engrave". To engrave dapat diartikan sebagai kata 'mengukir'. Sebagaimana ukiran yang tidak mudah hilang, begitu pula dengan karakter. Karakter yang telah melekat pada diri seseorang tidak akan mudah hilang dengan bertambahnya usia. (Asmaun Sahlan dan Angga Teguh Prasetyo:2012)

Suyanto mendefiniskan karakter sebagai cara berpikir dan berperilaku yang menjadi ciri khas tiap individu untuk hidup dan bekerja sama, baik dalam lingkup keluarga, masyarakat, bangsa dan negara. Individu yang berkarakter baik adalah individu yang bisa membuat keputusan dan siap mempertanggungjawabkan tiap akibat dari keputusan yang ia buat. Karakter adalah pola, baik itu pikiran, sikap, maupun tindakan yang melekat pada diri seseorang dengan sangat kuat dan sulit dihilangkan. (Abdullah Munir) 
Berdasarkan pendapat di atas karakter diartikan sebagai cara berpikir dalam bersikap dan berperilaku yang telah melekat kuat pada diri seseorang. Karakter sudah menjadi ciri khas yang kuat dari seseorang dalam bersikap dan berperilaku, baik di lingkungan keluarga, sekolah, masyarakat. Sebagaimana sebuah ukiran karakter yang telah melekat pada diri seseorang tidak akan mudah terkikis atau pun hilang.

Ahmad Tafsir mengatakan bahwa pendidikan dalam Islam adalah orang-orang yang bertanggung jawab terhadap perkembangan anak didik dengan mengupayakan perkembangan seluruh potensi anak didik baik potensi efektif, potensi kognitif maupun potensi psikomotorik. (Ahmad Tafsir :1992).

Oleh karena itu, hakekat pendidikan Islam adalah usaha orang dewasa muslim yang bertaqwa secara sadar mengarahkan dan membimbing pertumbuhan serta perkembangan fitrah anak didik melalui ajaran Islam ke arah titik maksimal pertumbuhan dan perkembangannya. (M. Arifin:1991) Pendidikan karakter bisa diartikan sebagai sebuah bantuan sosial agar individu itu dapat ber-tumbuh dalam menghayati kebebasannya dalam hidup bersama dengan orang lain dalam dunia. Pendidikan karakter bertujuan membentuk setiap pribadi menjadi insan yang berkeutamaan. (Z. Aqib:2011)

Berdasarkan pendapat beberapa ahli di atas maka dapat diambil kesimpulan pengertian karakter. Karakter adalah sikap dan perilaku, baik yang diwujudkan dalam bentuk pikiran, perasaan, atau pun tindakan yang menjadi ciri khas seseorang sehingga membedakannya dengan yang lain. Karakter sifatnya tidak mudah hilang, ia akan terus melekat pada diri yang memilikinya. Karakter juga dapat diartikan sebagai kepribadian atau watak. Karakter ini diperoleh dari proses internalisasi nilai-nilai yang didapatkan dari seluruh aktivitas manusia. Baik yang hubungannya dengan Tuhan, dengan sesama manusia, ataupun dengan lingkungan sekitarnya. Nilai-nilai tersebut berlandaskan pada norma-norma agama, hukum, tata karama, budaya, dan adat istiadat.

Selain itu, pendidikan juga merupakan proses internalisasi budaya ke dalam diri seseorang dan masyarkat sehingga membuat orang dan masyarakat jadi beradab. Pendidikan bukan merupakan sarana transfer ilmu pengetahuan saja, tetapi lebih luas lagi, yaitu sebagai sarana pembudayaan dan penyaluran nilai (enkulturasi dan sosialisasi). Anak harus mendapatkan pendidikan yang menyentuh dimensi dasar kemanusiaan. Dimensi kemanusiaan itu mencakup tiga hal paling mendasar, yaitu (1) Afektif, yang tercermin pada kualitas keimanan, ketakwaan, akhlak mulia termasuk budi pekerti luhur serta kepribadian unggul dan kompetisi estetis; (2) Kognitif, yang tercermin pada kapasitas pikir dan daya intelektualitas untuk menggali dan mengembangkan serta menguasai Iptek; (3) Psikomotorik, yang tercermin pada 
kemampuan mengembangkan keterampilan teknis, kecakapan praktis, dan kompetensi kinestetis.

Sedangkan karakter menurut Simon Philips dalam bukunya Muslich Mansyur mengatakan bahwa, karakter adalah kumpulan tata nilai yang menuju pada susatu sistem yang melandasi pemikiran, sikap dan perilaku yang ditampilkan. Sementara itu, Koesoema dalam bukunya Muslich Mansur juga berpendapat bahwa karakter sama dengan kepribadian. Kepribadian dianggap sebagai "ciri atau karakteristik atau gaya atau sifat khas dari diri seseorang yang bersumber dari bentukan-bentukan yang diterima lingkungan, misalnya keluarga pada masa kecil dan juga bawaan seseorang sejak lahir." Prof. Suyanto, menyatakan bahwa karakter adalah cara berpikir dan berperilaku yang menjadi cirri kahs tiap individu untuk hidup dan bekerja sama, baik dalam lingkup keluarga, masyarakat, bangsa dan Negara. Individu berkarakter baik adalah individu yang bisa membuat keputusan dan siap mempertanggungjawabkan tiap akibat dari keputusan yang ia buat. Imam Ghazali menganggap bahwa karakter lebih dekat dengan akhlak, yaitu spontanitas manusia dalam bersikap, atau perbuatan yang telah menyatu dalam diri manusia sehingga ketika muncul tidak perlu dipikirkan lagi. (Z.Aqib:2011)

Konsep penguatan pendidikan karakter dapat dilakukan melalui berbagai strategi pengintegrasian. Strategi yang dapat dilakukan adalah: (Z.Aqib:2011) (1) Pengintegrasian dalam kegiatan sehari-hari. Pelaksanaan strategi ini dapat dilakukan melalui cara keteladanan. Kegiatan ini bisa dilakukan oleh pengawas, kepala sekolah, guru, staf administrasi di sekolah yang dapat dijadikan model bagi peserta didik. Kegiatan spontan yaitu kegiatan yang dilakukan secara spontan pada saat itu juga. Kegiatan ini dilakukan pada saat guru mengetahui sikap peserta didik yang kurang baik, seperti meminta sesuatu dengan berteriak, mencoret dinding. Teguran dengan cara guru perlu menegur dan mengingatkan peserta didik yang melakukan perilaku buruk agar mengamalkan nilai-nilai yang baik sehingga guru dapat membantu mengubah tingkah laku mereka. Pengkondisian lingkungan dengan cara suasana sekolah dikondisikan sedemikian rupa dengan penyediaan sarana fisik. Contoh: penyediaan tempat sampah, jam dinding dan lain sebagainya. Kegiatan rutin yang merupakan kegiatan yang dilakukan peserta didik secara terus-menerus dan konsisten setiap saat. Contoh kegiatan berbaris masuk ruang kelas, berdoa kegiatan. (2) Pengintegrasian dalam kegiatan yang diprogramkan.Strategi ini dilaksanakan setelah terlebih dahulu guru membuat perencanaan atas nilai-nilai yang akan diintegrasikan dalam kegiatan tertentu. Hal ini dilakukan jika guru menganggap perlu memberikan pemahaman atau prinsip-prinsip moral yang diperlukan. 


\section{Pembentukan Karakter Siswa}

Penguatan pendidikan karakter kepada siswa yang diterapkan oleh SMK seKecamatan Margoyoso memiliki keragaman yaitu (1) SMK Cordova Margoyoso. Strategi yang digunakan dalam internalisasi di SMK Cordova secara umum dengan memberi pemahaman secara halus dan tegas kepada peserta didiknya melalui ceramah dan motivasi yang kemudian guru memberi contoh langsung, dan bagi mereka yang lulus sesuai harapan diberikan semacam reward ataupun sebaliknya kalau mereka tidak sesuai maka diberi panishmen. (2) SMK Salafiyah. Strategi yang digunakan adalah dengan membiasakan perilaku yang baik. (3) SMK Gajah Mada 01 Margoyoso. Strategi yang digunakan berupa ceramah kepada peserta didik kemudian diberi tugas untuk ketelatenan mereka. Hal itu dilakukan karena mayoritas peserta didiknya perempuan dan supaya mereka bisa menjadikan itu suatu kebiasaan. (4) SMK Kesuma Margoyoso. Strategi yang digunakan dengan cara bijaksana dan mauidhah hasanah. Selain itu, juga memakai ceramah, membaca, penugasan, diskusi praktek, penilaian. Dengan demikian komunikasi, motivasi serta memberi arahan juga bisa dijadikan keteladan supaya pembiasaan bisa sama-sama dilaksanakan secara seimbang serta adanya paneshmen dan reward. (5) SMK Terpadu Nusantara. Strategi dengan cara pendekatan kepada peserta didik. Hal itu dilakukan supaya peserta didik tahu dan mau menjalankan.

Media yang dipergunakan dalam pendidikan karakter kepada peserta didik di SMK se-Kecamatan Margoyoso yaitu (1) SMK Cordova Margoyoso. Media yang digunakan di SMK Cordova adalah keteladanan, meditasi/dzikir, kebiasaan, kepribadian, dan indoktrinasi. (2) SMK Salafiyah. Media yang digunakan di SMK Salafiyah adalah keteladanan, meditasi/dzikir, kebiasaan, dan indoktrinasi. (3) SMK Gajah Mada 01 Margoyoso. Media yang digunakan di SMK Gajah Mada adalah keteladanan dan kebiasaan. (4) SMK Kesuma Margoyoso. Media yang di SMK Kesuma adalah keteladanan dan kebiasaan. (5) SMK Terpadu Nusantara. Media yang di SMK Terpadu Nusantara adalah keteladanan.

Media-media yang digunakan dalam pendidikan karakter kepada peserta didik di SMK se-Kecamatan Margoyoso adalah:

\section{a. Media Keteladanan}

Keteladanan dijadikan sebagai media untuk mencapai tujuan pembelajaran Islam karena hakekat pendidikan Islam ialah mencapai keridhaan kepada Allah dan mengangkat tahap akhlak dalam bermasyarakat berdasarkan pada agama serta membimbing masyarakat pada rancangan akhlak yang dibuat oleh Allah Swt. untuk manusia. 
Media keteladanan ini dapat dibedakan menjadi keteladanan internal (internal modelling) dan keteladanan eksternal (external modelling). Keteladanan internal dapat dilakukan melalui pemberian contoh yang dilakukan oleh sendiri dalam proses pembelajaran. Sementara keteladanan yang kedua adalah keteladanan eksternal, yaitu keteladanan yang datang dari luar diri. Keteladanan semacam ini dapat dilakukan misalnya dengan menyajikan cerita tentang tokoh-tokoh agama yang dapat dijadikan sebagai teladan dalam meniti kehidupan. Misalnya, tokoh nabi Muhammad, para sahabat nabi Muhammad, Jenderal Besar Soedirman, dan tokohtokoh penting lain baik di Indonesia maupun di luar Indonesia yang patut untuk diteladani. Dengan demikian, media yang digunakan di SMK se-Kecamatan Margoyoso menggunakan media keteladanan tersebut, sehingga dalam interaksi pendidikan yang terjadi di sekolah, dilaksanakan dengan meneladankan sikap-sikap baik kepada peserta didiknya. Wujud konkritnya, guru mencontohkan tindakan-tindakan baik kepada peserta didiknya. Dalam catatan observasi, guru-guru SMK se-Kecamatan Margoyoso mencontohkan akhlak karimah dengan bersalaman kepada suami/istrinya atau orang tuanya ketika diantar.

\section{b. Media Pembiasaan}

Pembiasaan merupakan salah satu media yang sangat penting dalam penginternalisasian kepada peserta didik. Seseorang yang mempunyai kebiasaan tertentu akan dapat melakukannya dengan mudah dan senang hati. Bahkan, sesuatu yang menjadi kebiasaan dalam usia muda sulit dirubah dan tetap berlangsung sampai hari tua. Untuk mengubahnya seringkali dilakukan terapi dan pengendalian diri yang serius. Atas dasar inilah para ahli pendidikan senantiasa mengingatkan agar peserta didik segera dibiasakan dengan sesuatu yang diharapkan.

Pembiasaan sebenarnya merupakan suatu kegiatan yang diulang-ulang agar dapat dilakukan secara otomatis. Dalam proses pembiasaan, pendidik membiasakan pendidikan akhlak yang baik dan benar kepada peserta didik sebagai inti pendidikan. Dengan demikian, semua guru-guru di SMK se-Kecamatan Margoyoso menggunakan media keteladanan tersebut, sehingga dalam interaksi pendidikan yang terjadi di sekolah, dilaksanakan dengan membiasakan sikap-sikap baik kepada peserta didiknya. Dalam catatan observasi dan wawancara dengan guru-guru SMK se-Kecamatan Margoyoso membiasakan shalat dzuhur berjamaah dan ada pembacaan maulid Nabi.

\section{c. Meditasi/dzikir}

Meditasi sebagai disiplin metode dalam tradisi Islam baru muncul setelah adanya gerakan sufi. Meditasi yang dilakukan sebelum proses belajar di mulai banyak menunjukkan dampak baik seperti suasana kelas tidak ricuh, anak-anak tenang dan meningkatnya konsentrasi saat belajar serta apa bila anak-anak melakukan kesalahan 
mereka cepat menyadari untuk meminta maaf dan bersikap sopan. Dengan demikian, guru-guru di SMK se-Kecamatan Margoyoso menggunakan media meditasi tersebut hanya di SMK Cordova dan Salafiyah kepada peserta didiknya. Dalam catatan observasi dan wawancara dengan guru-guru SMK Cordova dan Salafiyah yang membaca bersama-sama asmaul husna.

\section{d. Indoktrinasi}

Indoktrinasi merupakan bagian dari media pembelajaran yang berorientasi pada nilai (afek). Ada beberapa tahap dalam indoktrinasi ini, yaitu: (1) tahap brainwashing, melalui tanya jawab, wawancara mendalam dengan teknik dialektika, dan lain-lain. (2) tahap mendirikan fanatisme, menggunakan pendekatan emosional daripada rasional. (3) tahap penanaman doktrin, memakai pendekatan emosional atau keteladanan. Dengan demikian, guru-guru di SMK se-Kecamatan Margoyoso yang melakukan media indoktrinasi hanya di SMK Cordova dan Salafiyah. Dalam catatan observasi dan wawancara dengan guru-guru SMK Cordova dan Salafiyah adanya mata pelajaran keNU-an yang diajarkan di kelas.

\section{e. Behivior/Kepribadian}

Kepribadian guru agama Islam yang harus dimiliki dalam diri pribadi guru setidaknya ada empaat kepribadian. Kepribadian tersebut antara lain: (1) kepribadian mantap, (2) kepribadian stabil, (3) dewasa, dan (4) arif. Dalam catatan observasi yang peneliti lakukan terhadap guru SMK bahwa semua guru mempunyai mempunyai hal tersebut, karena waktu pembelajaran di dalam kelas peserta didik dapat terkondisikan. Hanya saja ada masih ada beberapa peserta didik yang kelihatan kegelisahan atau tidak fokus dalam proses pembelajaran di kelas.

\section{Kesimpulan}

Penelitian ini menyimpulkan bahwa media yang digunakan dalam pendidikan karakter kepada peserta didik di SMK se-Kecamatan Margoyoso adalah: 1) Media Keteladanan; 2) Media Pembiasaan; 3) Meditasi/dzikir; 4) Indoktrinasi; 5) Behivior/Kepribadian. Penelitian menemukan bahwa semua guru mempunyai (1) kepribadian mantap, (2) kepribadian stabil, (3) dewasa, dan (4) arif karena waktu pembelajaran di dalam kelas peserta didik dapat terkondisikan. Hanya saja masih ada beberapa peserta didik yang kelihatan kegelisahan atau tidak fokus dalam proses pembelajaran di kelas. 


\section{DAFTAR PUSTAKA}

Abdullah Munir. Pendidikan dalam Perspektif Paradigma Islam.

Ahmad Tafsir.1992. Ilmu Pendidikan dalam Persepsi Islam.Bandung: RosdaKarya.

Al-Rasyidin dan Syamsul Nizar, Filsafat Pendidikan Islam.2005. Jakarta: Ciputat Press.

Asmaun Sahlan dan Angga Teguh Prasetyo.2012. Desain Pembelajaran Berbasis Pendidikan Karakter.Yogyakarta: Ar-Ruzz Media.

J.P. Chaplin.2005. Kamus Lengkap Psikologi. Jakarta: Raja Grafindo Persada.

Jalaludin. Pikologi Agama.2001.Jakarta: Raja Grafindo Persada.

Lestari, W. M., \& Zafi, A. A. (2020). Implementasi Strategi Pembelajaran Pendidikan Karakter Bagi Usia Anak MI/SD. PEDAGOGIA, 18(2). https://doi.org/10.17509/PDGIA.V18I2.24609

Lexy Moeloeng.2004. Metodologi Penelitian Kualitatif. Bandung: PT. Remaja RosdaKarya.

M. Arifin. 1991.Ilmu Pendidikan Islam Suatu Tinjauan Teoritis dan Praktis Berdasarkan Pendekatan Interdisipline. Jakarta: Bumi Aksara

M. B. Miles and Huberman.1992.Qualitative Data Analysis.Boston: Sage Publication, Inc.

Marleny Leasa.2017. Full Day School Dalam Pembentukan Karakter Siswa SMKN 13 Malang, (Jurnal Ilmu Sosial dan Humaniora, Vol 6, No 1 (2017); https://ejournal.undiksha.ac.id/index.php/JISH/article/view/9903/6370.

Muhaimin dkk,.2008. Paradigma Pendidikan Islam Upaya Mengefektifkan Pendidikan Agama Islam di Sekolah.Bandung: PT Remaja Rosdakarya.

Nafisah, F. T., \& Zafi, A. A. (2020). Model Pendidikan Karakter Berbasis Keluarga Perspektif Islam di Tengah Pendemi Covid-19. Ta'allum: Jurnal Pendidikan Islam, 08(1), 1-20. https://doi.org/10.21274/taalum.2020.8.1.1-20

Naiyya Balaya, A., \& Zafi, A. A. (2020). Peranan Kearifan Dalam Pembentukan Karakter Peserta Didik. Journal of Civics and Education Studies, 7(1), 27-34. http://openjournal.unpam.ac.id/index.php/PKn/article/view/4791

Septiani, G. (2020). Pengaruh Lingkungan Bagi Kecerdasan Siswa Secara Intelektual, Emosional, Sosial, dan Spiritual. Al Hikmah: Journal of Education, 1(1), 47-58. http://ejournal.yphn.ac.id/index.php/Alhikmah/article/view/6

Sanapiah Faisal.1990. Penelitian Kualitatif: Dasar-Dasar dan Aplikasi.Malang: YA3,

Sugiyono.2013.Metode Penelitian Pendidikan, Pendekatan Kuantitatif, Kualitatif dan R\&D.Bandung: Alfabeta, 2013.

Sukardi.2003. Metode Penelitian Pendidikan, Kompetensi dan Prakteknya, Jakarta: Bumi Aksara. 
Abdul Karim, Retno Susilowati, dan Muslim

Sutrisno Hadi. 1989.Metodologi Research.Yogyakarta: Andi Offset.

Z. Aqib.2011. Pendidikan Karakter Membangun Perilaku Positif Anak Bangsa, Bandung: Yrama Widya.

Zafi, A. A. (2020b). Pemahaman dan Penghayatan Peserta Didik tentang Ibadah dalam Pembelajaran Fiqih di MI Manafiul Ulum Gebog Kudus. Elementary: Jurnal Ilmiah Pendidikan Dasar, 6(1), 47-58. https://doi.org/10.32332/ELEMENTARY.V6I1.1692. 